Revista de Biología Marina y Oceanografía

Vol. 52, N³: 635-639, diciembre 2017

DOI 10.4067/S0718-19572017000300020

\title{
RESEARCH NOTE \\ Screening for WSSV in crustacean from marine areas of Buenos Aires, Argentina
}

\author{
Examen para WSSV en crustáceos de áreas marinas \\ de Buenos Aires, Argentina \\ Sergio R. Martorelli1 ${ }^{*}$, Paula Marcotegui ${ }^{1}$, \\ Martin Montes ${ }^{1}$ and Carlos Javier Panei ${ }^{2}$
}

\begin{abstract}
${ }^{1}$ Laboratorio de Parásitos de Peces, Crustáceos y Moluscos, CEPAVE (CCT-LA PLATA-CONICET-UNLP) - Centro de Estudios Parasitológicos y de Vectores, Boulevard 120 s/n (1900) La Plata, Buenos Aires, Argentina. *sergio@cepave.edu.ar

${ }^{2}$ Laboratorio de Virología, Facultad de Ciencias Veterinarias, Universidad Nacional de La Plata, Casilla de Correo 296, La Plata, Buenos Aires, Argentina
\end{abstract}

\begin{abstract}
In total 374 specimens corresponding to four species of shrimp: Artemesia longinaris, Pleoticus muelleri, Peisos petrunkevitchii, Palaemon macrodactylus, and two species of crabs: Neohelice granulata and Cyrtograpsus angulatus were studied in the search of white spot syndrome virus (WSSV). The crustaceans were collected in the estuary of Bahia Blanca, the port of Mar del Plata and the Samborombón Bay, Argentina, between 2010 and 2014. A polymerase chain reaction (PCR) analysis in all of them has not detected any virus presence. These new results suggest that the discovery of infected shrimp in 2008-09 in the Bahia Blanca estuary may have been a one-time local event, promoted by special conditions of seawater temperature inside the estuary, coincident with the presence of a virus carrier or transporter. To determine if the virus was finally installed in the estuary of Bahia Blanca more screening are needed coming from a larger number of shrimp samples. These studies will be necessary mainly in A. longinaris (Penaeidae) since this family of shrimps is most susceptible to be affected by WSSV.
\end{abstract}

Key words: Shrimps, crabs, WSSV, Argentina

\section{INTRODUCTION}

Since 1992, in the Laboratory of Parasites of Fishes, Crustaceans and Mollusks, macro and micro parasites of crustaceans from the South Atlantic Ocean have been investigated. Different parasites were reported in several species of crustaceans (shrimps and prawns) from freshwater, marine and estuarine environments (Martorelli 1989, 1992; Martorelli \& Schuldt 1990, Martorelli \& Higgins 2004, Martorelli et al. 1994, 1999, 2002, 2012; Sardella \& Martorelli 1997). Recently, Martorelli et al. (2010) reported the viral pathogens WSSV from the shrimps Artemesia longinaris, Palaemon macrodactylus and the crab Cyrtograpsus angulatus in the estuary of Bahia Blanca, Argentina. That report was the most austral occurrence for the virus in the South Atlantic Ocean. In relation with the more commercially important argentine red shrimp Pleoticus muelleri, Martorelli et al. (2010), Roccamo et al. (2010) and Costagliola et al. (2011) did not find specimens infected by WSSV.

It is also important to consider that in some nearby water areas of Brazil, several reports of the virus in natural populations of crustaceans were published (Marques-Muller 2011, Cavalli et al. 2010, 2011). The report of WSSV in Argentina was coincident with a very slight increase of seawater temperature this in relation to previous periods (IADO 2008, 2009; Freije
\& Marcovecchio 2004). According to Beigt \& Piccolo (2003) and Beigt (2007), the increase of temperature could have been related to a slow warming of the estuary system. On the other hand, it is known that WSSV is extremely dependent on temperature, which is crucial for their proliferation (Gao et al. 2011, Moser et al. 2012). The virus replicates faster at high temperatures (Jiravanichpaisal et al. 2004). Generally between $25^{\circ} \mathrm{C}$ and $27^{\circ} \mathrm{C}$ is the optimum temperature for its proliferation, while it is fully suspended at $4{ }^{\circ} \mathrm{C}$ (Jiravanichpaisal et al. 2004, Wongmaneeprateep et al. 2010). Thi-Lua \& Hirono (2015) working with the shrimp Marsupenaeus japonicus showed that WSSV infection is temperature-dependent and shrimp are highly susceptible to infection at $25^{\circ} \mathrm{C}$. Low temperatures $\left(15^{\circ} \mathrm{C}\right)$ reduce the replication rate of the virus and the hosts remain as carriers that could disperse the infection when the water temperature increases. Du et al. (2006) studied the effect of the hyperthermia in Procambarus clarkia and observed no mortality when crayfish were at $32 \pm 1{ }^{\circ} \mathrm{C}$, and $100 \%$ mortality at $24 \pm 1{ }^{\circ} \mathrm{C}$. The authors reported viral charges of $10^{5}$ copies $\mathrm{mg}^{-1}$ tissue at $32 \pm 1^{\circ} \mathrm{C}$ instead $10^{4}$ to $10^{10}$ copies $\mathrm{mg}^{-1}$ tissue at $24 \pm 1{ }^{\circ} \mathrm{C}$. At higher temperatures the virus is inactivated in $120 \mathrm{~min}$ at $50{ }^{\circ} \mathrm{C}$ and $1 \mathrm{~min}$ at $60^{\circ} \mathrm{C}$ (Lo 2012). 
The screening presented in this paper was conducted to increase the still low numbers of crustaceans tested in the studied area after the mentioned report (Martorelli et al. 2010). In addition, some comments about the possible relationship between water temperatures in the Bahia Blanca Estuary and the WSSV are presented.

\section{MATERIALS AND METHODS}

Crustaceans used in this study, more than 600, were collected from late 2010 to 2014, usually in February and March of each year. In the laboratory all the crustaceans were observed under a binocular microscope to determine the existence of spots on the carapace (Martorelli et al. 2010). Subsequently, a subsample of specimens corresponding to four species of shrimp: Artemesia longinaris $(\mathrm{n}=187)$, Pleoticus muelleri $(\mathrm{n}=85)$, Peisos petrunkevitchii $(\mathrm{n}=15)$, Palaemon macrodactylus $(\mathrm{n}=64)$, and two species of crabs: Neohelice granulata $(\mathrm{n}=7)$ and Cyrtograpsus angulatus $(\mathrm{n}=16)$ were studied in the search of the virus (Table 1). Those crustaceans were obtained in various ways. Some were purchased fresh at the Ingeniero White fishing port (38 $47^{\prime} 26^{\prime \prime} \mathrm{S} ; 6^{\circ} 16^{\prime} 12^{\prime \prime} \mathrm{W}$ ), after commercial vessels trawling channels of the Bahia Blanca estuary captured them. Others were collected using cast nets or crab-traps in Puerto Cuatreros, General Daniel Cerri (38 45'05'S; 62 22'46"'W), in Mar del Plata coast (3800'26''S; 57³2'17''W), in Samborombon Bay (35'44'46'S; 57²2'52'W). Finally, other shrimps were captured by an oceanographic survey in the Vessel ARA Puerto Deseado from 'el Rincon' area (3944'24”'S; 6416'00”'W).
Sampling sites were chosen mainly considering the site where the virus was found in 2008-2009 (Bahia Blanca Estuary). In addition, in this study specimens of $P$. macrodactylus from Samborombon Bay were included, a new place reported for this alien shrimp (Martorelli et al. 2012), and also specimens of Pleoticus muelleri from Mar del Plata because of the commercial importance of this crustacean in Argentina.

Whole crustaceans were immediately fixed in $95^{\circ}$ molecular grade ethanol. DNA was extracted mainly from the gills (main tissue where the virus was detected in the crustaceans of the Bahia Blanca Estuary), but also from skeletal muscle and hepatopancreas, using the DNeasy kits (Quiagen) methodology. Extracted DNA was quantified by an Ampliquant AQ07 spectrophotometer. PCR-amplification was conducted on the extracted DNA using GoTaq ${ }^{\circledR}$ Green Master Mix (Promega) kit. For virus detection 3 different methods were used: A nested PCR reaction using the primer set WS800/ WS500 (Martorelli et al. 2010), a modified one step PCR, which can detect WSSV virions from different geographical regions (Nunan et al. 2011) and the commercial primer set IQ2000 (Farming IntelliGene Tech, Taipei, Taiwan) that could discriminate different levels of infection. The controls included in the commercial kit IQ2000 and the extracted DNA from infected Litopenaeus vanname $i$ were used as positive controls. These mentioned infected shrimps were collected from a WSSV outbreak in Costa Rica and were provided by the Laboratorio de Patologías y Parasitología de Crustáceos, Nicoya, Guanacaste, Costa Rica.

Table 1. Species of shrimps and crabs screening, tissue examined, number of specimens analyzed, locality, and year of capture / Detalle de los camarones y cangrejos estudiados, tejido examinado, número de especímenes, localidad y año de captura

\begin{tabular}{lcclc}
\hline \multicolumn{1}{c}{ Species } & Tissue & N & \multicolumn{1}{c}{ Locality } & Date \\
\hline Artemesia longinaris & gills-muscle & 71 & Ingeniero White & Feb/Mar-2010 \\
Artemesia longinaris & gills-hepato & 70 & El Rincón & Ene-2011 \\
Artemesia longinaris & gills & 16 & Ingeniero White & Feb-2011 \\
Artemesia longinaris & gills-muscle & 30 & General D. Cerri & Mar-2014 \\
Cyrtograpsus angulatus & gills & 16 & General Cerri & Feb-2010 \\
Neohelice granulata & gills & 7 & General Cerri & Feb-2010 \\
Palaemon macrodactylus & gills & 15 & General Cerri & Feb-2010 \\
Palaemon macrodactylus & gills & 19 & Samborombon Bay & Mar-2011 \\
Palaemon macrodactylus & gills & 10 & General D. Cerri & Mar-2012 \\
Palaemon macrodactylus & gills & 10 & General Cerri & Feb-2013 \\
Palaemon macrodactylus & gills & 10 & General Cerri & Feb-2014 \\
Pleoticus muelleri & gills & 35 & Ingeniero White & Feb/Mar-2010 \\
Pleoticus muelleri & gills & 25 & Mar del Plata & Ene-2012 \\
Pleoticus muelleri & gills & 25 & Ingeniero White & Mar-2013 \\
Peisos petrunkevitchii & gills & 15 & General Cerri & Feb-2010 \\
\hline
\end{tabular}




\section{RESULTS AND DISCUSSION}

From 2010 to 2014 more than 600 shrimps and crabs were examined for external and histological signs of WSSV. The crustaceans were observed under a binocular microscope to determine the existence of spots on the carapace, same as they had been observed in a previous study (Martorelli et al. 2010). As a result all of specimens were negative. Subsequently, of the total of crustaceans more than $50 \%$ (374) were chosen at random and examined by PCR using the previously indicated primers. All these crustaceans analyzed were negative for WSSV (Table 1).

Martorelli et al. (2010) found, using Real Time Quantitative PCR (qPCR) a low viral copy number $\left(7.3 \times 10^{1}\right.$ to $3.96 \mathrm{X}$ $10^{4}$ ) in the infected crustaceans studied, and only one shrimp showed magnitude values close to $10^{4}$. Normal values in outbreaks are near to $10^{4}-10^{10}$ (Ligthner 2003). These low viral copies found in the infected shrimp in 2008-2009 may have been one of the factors that conditioned the expansion of the virus in the Bahia Blanca Estuary. During the period 2008-2009, in which WSSV was detected, Bahia Blanca Estuary showed a significant variation in seawater surface temperature anomalies (GISTEMP Team 2016, Hansen $e t$ al. 2010). This could be related to the assertions of Tendencia \& Verreth (2010), who exposed that a fluctuation of $3{ }^{\circ} \mathrm{C}$ or $4{ }^{\circ} \mathrm{C}$ in water temperature can trigger outbreaks of WSSV in culture conditions. According to the Goddard Institute for Space Studies $(2008)^{1}$, the year 2008 was one of the warmest years since the period of instrumental measurements.

In conclusion, since the original report of WSSV in Bahia Blanca Estuary (Martorelli et al. 2010) an annual screening was carried out on many crustaceans and positive crustaceans for WSSV were not found with the PCR methods used. These new results suggest that the discovery of infected shrimp in 20082009 in the Bahia Blanca Estuary may have been a one-time local event, promoted by special conditions of seawater temperature inside the estuary, coincident with the presence of a virus carrier or transporter. The number of crustaceans examined should be increased considering the dilution effect of the environment and the low prevalence of the virus in natural environments. Takur et al. (2002) suggest, in a study of evaluation of WSSV in postlarvae, analysis of at least 300 crustaceans in pools to reduce the probability of false negatives.

Until now only infected specimens were found in Argentina in samples taken during 2008-2009 (Martorelli et al. 2010). At that time, 11 of 25 specimens of the shrimp Artemesia longinaris, 4 of 6 crabs Cyrtograpsus angulatus and 1 of 5 shrimp Palaemon macrodactylus, were found infected with WSSV. Those specimens were analyzed by PCR and qPCR.

\footnotetext{
${ }^{1}<$ http://data.giss.nasa.gov/gistemp/2008/>
}

All the shrimp examined by PCR between 2010 and 2014 were negative for WSSV. In addition to the results presented here, it is important to take into account the negative results obtained by Roccamo et al. (2010) and Costagliola et al. (2011) for Pleoticus muelleri. To determine if the virus was finally installed in the Bahia Blanca Estuary more studies are needed coming from a larger number of shrimp samples. These studies will be necessary mainly in the species Artemesia longinaris (Penaeidae), because this family of shrimps is most susceptible to be affected by WSSV (Lightner 2003).

\section{ACKNOWLEDGEMENTS}

We thank the anonymous reviewers for their critical review of the manuscript, to Esp. Sabrina L. Martorelli from Wilmington Plc., London for editing the final version of the manuscript and to Agr. Ind. Alexander Varela M. from the Laboratorio de Patologías y Parasitología de Crustáceos, Nicoya, Costa Rica, who provided infected shrimp in alcohol for use as positive control of WSSV. This work was partially funded by a research Grant from the Consejo Nacional de Investigaciones Científicas y Técnicas (PIP 0257) to S. R. M.

\section{LITERATURE CITED}

Beigt D \& MC Piccolo. 2003. Estudio de la temperatura del agua en relación con la abundancia del microzooplancton en Puerto Cuatreros, estuario de Bahía Blanca. Contribuciones Científicas GAEA, Sociedad Argentina de Estudios Geográficos, pp. 49-55.

Beigt D. 2007. Balance energético de las planicies de marea del estuario de Bahía Blanca y su relación con la productividad plantónica del estuario. Tesis Doctoral, Departamento de Geografía, Universidad Nacional del Sur, Buenos Aires, 344 pp.

Cavalli LS, BFS Nornberg, SA Netto, L Poersch, LA Romano, LF Marins \& PC Abreu. 2010. White spot syndrome virus in wild penaeid shrimp caught in coastal and offshore waters in the southern Atlantic Ocean. Journal of Fish Diseases 33: 533-536.

Cavalli LS, LA Romano, LF Marins \& PC Abreu. 2011. First report of white spot syndrome virus in farmed and wild penaeid shrimp from Lagoa Dos Patos estuary, southern Brazil. Brazilian Journal of Microbiology 42: 1176-1179.

Costagliola M, V Jurquiza, C Fischbach, G Spanjersberg, G Andreoli, P Moriondo \& J De La Garza. 2011. Ausencia del virus del síndrome de la mancha blanca (WSSV) en muestras de langostino (Pleoticus muelleri) desembarcado en el Puerto de Rawson entre Noviembre de 2010 y Marzo de 2011. INIDEP, Informe de Investigación 66: 1-11. <http://www.revistapuerto.com.ar/wp-content/ uploads/2014/05/282.pdf> 
Du HH, W-Fn Li, Z-R Xu \& Z-S Kil. 2006. Effect of hyperthermia on the replication of white spot syndrome virus (WSSV) in Procambarus clarkii. Diseases of Aquatic Organism 71: 175-178.

Freije RH \& JE Marcovecchio. 2004. Oceanografía química del estuario de Bahía Blanca. En: Piccolo MC \& M Hoffmeyer (eds). El ecosistema del estuario de Bahía Blanca 8: 69-78. IADO, Bahía Blanca.

Gao H, J Kong, ZJ Li, GX Xiao \& XH Meng. 2011. Quantitative analysis of temperature, salinity and $\mathrm{pH}$ on WSSV proliferation in Chinese shrimp Fenneropenaeus chinensis by real-time PCR. Aquaculture 312: 26-31.

GISTEMP Team. 2016. GISS Surface Temperature Analysis (GISTEMP). NASA Goddard Institute for Space Studies. $<$ http://data.giss.nasa.gov/gistemp/>

Hansen J, R Ruedy, M Sato \& K Lo. 2010. Global surface temperature change. Reviews of Geophysics 48, RG4004, <doi:10.1029/2010RG000345>

IADO. 2008. Programa de monitoreo de la calidad ambiental de la zona interior del estuario de Bahía Blanca. Informe Final, Instituto Argentino de Oceanografía, 103 pp. <https:// www.bahia.gob.ar/subidos/cte/informes/ria_final_ 06_07.pdf>

IADO. 2009. Programa de monitoreo de la calidad ambiental de la Zona Interior del Estuario de Bahía Blanca. Informe Final, Instituto Argentino de Oceanografía, 89 pp. <http:// www.bahiablanca.gov.ar/cte/doc/inf09_quimicamarina.pdf>

IADO. 2010. Programa de monitoreo de la calidad ambiental de la zona interior del estuario de Bahía Blanca. Informe Final, Instituto Argentino de Oceanografía, 122 pp. <https:/ /www.bahia.gob.ar/subidos/cte/informes Informe_ Final_Quimica_Marina_del_Estuario_de_Bahia_Blanca _2010.pdf>

Jiravanichpaisal P, K Söderhäll \& I Söderhäll. 2004. Effect of water temperature on the immune response and infectivity pattern in white spot syndrome virus (WSSV) in freshwater crayfish. Fish and Shellfish Immunology 17: 265-275.

Lightner DV. 2003. The penaeid shrimp viral pandemics due to IHHNV, WSSV, TSV and YHV: history in the Americas and current status. In: Proceedings of the 32nd Joint UJNR Aquaculture Panel Symposium, Davis and Santa Barbara, California, USA, 2003, pp. 17-20. <https://www. semanticscholar.org/paper/The-Penaeid-Shrimp-ViralPandemics-due-to-IHHNV-WS-Lightner/9e8dbd236f2 de2b09762d6eb63b92d3beac88c99>

Marques JS, IC Muller, JR Moser, TC Sincero \& MRF Marques. 2011. Wild captured crab, Chasmagnathus granulata (Dana, 1851), a new host for White Spot Syndrome Virus (WSSV). Aquaculture 318: 1-2.

MartorelliSR. 1989. El rol de Cyrtograpsus angulatus(Crustacea; Brachiura) en los ciclos de vida de Microphalus szidati (Digenea; Microphallidae) y Falsifillicollis chasmagnathi (Acanthocephala, Fillicollidae). Algunos aspectos de su ecología parasitaria. Memórias do Instituto Oswaldo Cruz 84(4): 567-574.
Martorelli SR. 1992. Parasites of the commercial shrimps and fishes in Argentine Sea: On the adult and metacercaria of Opecoeloides feliciae sp. n. (Digenea, Opecoelidae) Memórias do Instituto Oswaldo Cruz 87(1): 43-49.

Martorelli SR. 2002. Parásitos y epibiontes del Langostino Pleoticus muelleri (Bate 1888) en Atlántico Sud-occidental. En: Primer Congreso Iberoamericano Virtual de Acuicultura, Universidad de Zaragoza, Zaragoza, pp. 647-665. <https:// www.yumpu.com/es/document/view/14326313/parasitos-yepibiontes-del-langostino-pleoticus-revista-aquatic>

Martorelli SR \& RP Higgins. 2004. Kinorhyncha from the stomach of the shrimp Pleoticus muelleri (Bate, 1888) from Comodoro Rivadavia, Argentina. Zoologischer Anzeiger 243(1-2): 85-99.

Martorelli SR \& M Schuldt. 1990. Encapsulación de dos metacercarias (Digenea, Microphallidae) en Cyrtograpsus angulatus y Palaemonetes argentinus (Crustacea, Decapoda). Revista de Biología Tropical 38(2a): 295-304.

Martorelli SR, J Etchegoin \& JC Mallo. 1994. Presencia del hirudineo Stibarobdella macrothela sobre Pleoticus muelleri (Crustacea: Solenoceridae) en Argentina. Neotrópica 40: 89-90.

Martorelli SR, S Fumagalli \& F Cardillo. 1999. Estudio comparado de la fauna parasitaria de Artemesia longinaris (Crustacea, Decapoda) en los principales puertos camaroneros del Mar Argentino. Neotropica 45: 51-58.

Martorelli SR, R Overstreet \& J Janovich. 2010. First report of viral pathogens WSSV and IHHNV in Argentine Crustaceans. Bulletin of Marine Science 86(1): 117-131.

Martorelli SR, P Alda, P Marcotegui, MM Montes \& LF Sala. 2012. New locations and parasitological findings for the invasive shrimp Palaemon macrodactylus in temperate southwestern Atlantic coastal waters. Aquatic Biology 15: 153-157. <http://dx.doi.org/10.3354/ab00415>

Moser JR, DA Galván Álvarez, F Mendoza-Cano, T Encinas-Garcia, DE Coronado-Molina, G PortilloClark, MRF Marques, FJ Magallón-Barajas \& J Hernández-López. 2012. Water temperature influences viral load and detection of White Spot Syndrome Virus (WSSV) in Litopenaeus vannamei and wild crustaceans. Aquaculture 326-329: 9-14.

Nunan LM \& DV Lightner. 2011. Optimized PCR assay for detection of white spot syndrome virus (WSSV). Journal of Virological Methods 171(1): 318-321.

Roccamo AM, PM Cervellini, MC Piccolo \& FJ Barrantes. 2010. Optimización de una técnica para la detección de patologías virales en Pleoticus muelleri (Bate, 1988) en el estuario de Bahía Blanca, Argentina. Geoacta 35:40-44.

Sardella NH \& SR Martorelli. 1997. Occurrence of merogony of Agreggata frenzel, 1885 (Apicomplexa) in Pleoticus muelleri and Artemesia longinaris (Crustacea: Natantia) from patagonian waters (Argentina). Journal of Invertebrate Pathology 70: 198-202. 
Tendencia EA \& JAJ Verreth. 2011. Temperature fluctuation, low salinity, water microflora: risk factors for WSSV outbreaks in Penaeus monodon. Israeli Journal of AquacultureBamidgeh 63: 1-7.

Thakur PC, F Corsin, JF Turnbull, KM Shankar, NV Hao, PA Padiyar, M Madhusudhan, KL Morgan \& CV Mohan. 2002. Estimation of prevalence of white spot syndrome virus (WSSV) by polymerase chain reaction in Penaeus monodon postlarvae at time of stocking in shrimp farms of Karnataka, India: a population-based study. Diseases of Aquatic Organisms 49(3): 235-243.
Thi-Lua D \& I Hirono. 2015. Effect of low temperature on the pathogenicity of White Spot syndrome Virus (WSSV) in Kuruma shrimp (Marsupenaeus japonicus). Journal of Science and Development 113(8): 1405-1414

Wongmaneeprateep S, N Chuchird, P Baoprasertkul, P Prompamorn, K Thongkao \& C Limsuwan. 2010. Effects of high water temperature on the elimination of White Spot Syndrome virus in juveniles of Litopenaeus vannamei. Kasetsart University Fisheries Research Bulletin 34: 14-26.

Received 19 December 2016 and accepted 27 November 2017

Editor: Claudia Bustos D. 